\title{
Beach quality assessment as a tool for promoting sustainability in tourist islands: the case study of Oléron Island, France
}

\author{
V. Duvat \\ Department of Geography, Institute of Littoral and Environment, \\ La Rochelle University, France
}

\begin{abstract}
The research programme "Qualibeach" was launched in 2008 to support the implementation of the public policy "Oléron Coastal Quality" initiated the same year by the District Planning Community of Oléron Island (off the Atlantic coast of France). This policy is the first practical trial of ICZM (Integrated Coastal Zone Management) principles. It was set up for the improvement of beach quality so as to meet environmental, social and economic goals. The "Qualibeach" programme has an experimental value as it aims at perfecting a transferable collaborative procedure as well as delivering tools for sustainable development at the local scale. This paper firstly sheds new light on some key issues relating to the role of tourism in coastal development and the local promotion of sustainability. It then presents the scientific procedure, methods and results obtained, and examines the main benefits and difficulties met at this stage.
\end{abstract}

Keywords: Beach quality, ICZM, sustainable development, coastal tourism, Oléron Island, France.

\section{Introduction}

Until now, the main objectives of scientific programmes related to sustainable development projects based upon coastal quality were to improve knowledge of beach user preferences as a major factor affecting beach quality and also to build indicators for the assessment and monitoring of quality. The major works are those of Morgan and Williams [1], De Ruyck et al. [2], Morgan [3], Cendrero 
and Fischer [4], Cendrero et al. [5], Pereira et al. [6], Micallef and Williams [7], Ergin et al. [8,9], Cervantes and Espejel [10], although this list is by no means exhaustive. These authors have highlighted both the major role of scientific studies for supporting sustainable development at the local scale and the complexity of coastal quality assessment.

This paper presents a new ICZM (Integrated Coastal Zone Management) project based on beach quality, the Oléron Coastal Quality Project (OCQP), which was established in 2008 on Oléron Island off the Atlantic coast of France. Initially, the article examines the collaborative process developed between practitioners and scientists, and the methods of project implementation, as they are the major drivers of its success. Secondly, we describe the role of the scientific programme "Qualibeach" in the implementation of the OCQP through the presentation and discussion of recent results. The main benefits and difficulties of establishing sustainable development are discussed in the conclusion.

\section{From coastal challenges to the establishment of a collaborative programme for the improvement of beach quality}

The high economic value of the littoral zone in a multi-usage context and the recent identification of management issues have played a major role in the formation and implementation of a territorial project focused on coastal quality.

\subsection{Site study: main issues and challenges}

\subsubsection{Brief presentation of Oléron Island}

The islands of Ré and Oléron play a major role in the tourist attractiveness of the department of Charente-Maritime as they offer valuable landscapes, numerous beaches and an Atlantic character based upon natural and cultural assets that are well appreciated by national and foreign visitors [11].

With a land area of $175 \mathrm{~km}^{2}$, the island of Oléron has a permanent population of 21438 inhabitants distributed over eight rural districts, each numbering between 800 and 5900 inhabitants (Fig. 1). The permanent economic activities are agriculture, fishing and shellfish farming. Agricultural land covers $20 \%$ of the island's area, the fishing harbour of la Cotinière is ranked $11^{\text {th }}$ in France and oyster farming is still an active economic sector in addition to tourism. Oléron Island is easily accessible from the mainland to which it is connected by a tollfree bridge. Tourist accommodation comprises 50 hotels, 70 campsites and numerous residences. Secondary residences also constitute a major part of the tourist accommodation, reaching $58 \%$ on average and up to $79 \%$ in some villages. The island's heritage is both cultural, with 13 listed historical monuments such as forts, lighthouses and castles, and also natural, with $46 \%$ of its total surface is made up of listed ecological habitats, mostly sand dunes and wetlands. 


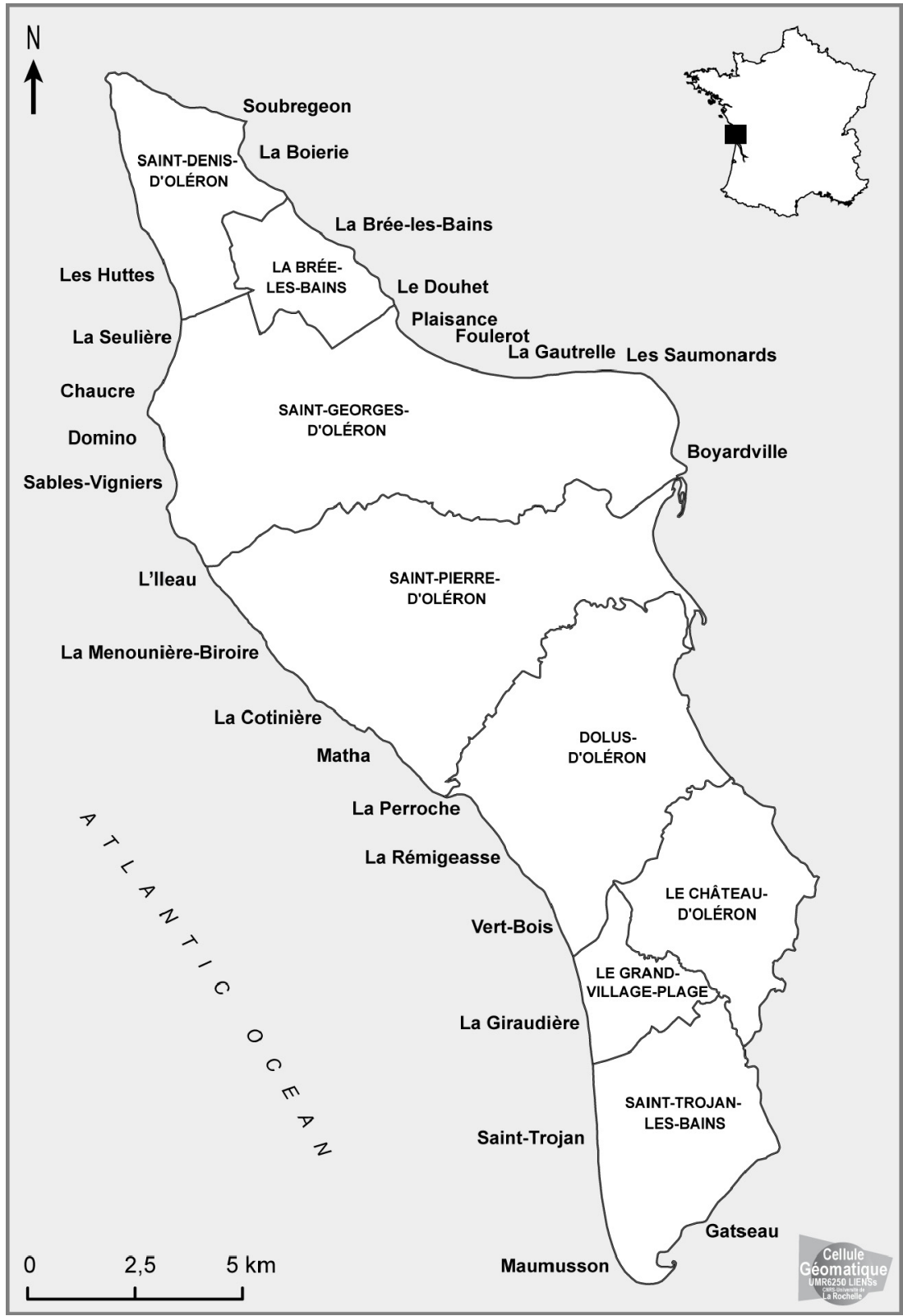

Figure 1: $\quad$ Location of Oléron Island beaches.

\subsubsection{Beach tourism and beach types}

An aerial counting campaign conducted on 15 July 2008 between 4 and 5 p.m. (peak hours) established that beach attendance reaches 15943 users, and is 
almost equally distributed between the western (8856) and eastern (7087) coasts [12].

According to the beach typology elaborated by A. Micallef and Williams [7], three beach types can be identified at Oléron Island: 1) village associated beaches, that are the most common and the most visited; 2) isolated beaches (south-western coast), that are reachable only by bicycle, on foot or by tourist train, and are much less frequented; and 3) campsite beaches. There are no wholly urban beaches, nor entirely rural ones. Non-secluded beaches all offer a minimum level of facilities and services. Since village associated beaches are by far the most numerous and the most frequented, they concentrate coastal issues and challenges. Their central areas offer diverse facilities and services (car parks, cycle tracks, security posts, toilets, information sources, phone facilities, bather zonation markers, rubbish bins, snack outlets, water sport centres...) while they have much wilder peripheries consisting of extended sand dunes covered with pine forests, which offer fewer facilities (generally a car park, cycle tracks and rubbish bins). The two main differences between the central sections of village beaches and urban beaches are that the seafront of the former does not have shops, hotels... and, in most cases, village beaches retain a dune between the beach and the road or buildings.

\subsubsection{Main management issues related to beach tourism}

The main problems identified on Oléron Island beaches are: 1) the emergence of land-use and water-use conflicts, due to the diversification of beach practices and an increase in the number of beach users; 2) the common violation of laws by beach users; 3) a decrease in personal security; and 4) the acceleration of sand dune degradation. These problems, which are common in coastal tourist areas, are mainly due to a lack of organization and control of coastal activities.

As listed in the Charter of Sustainable Development of the Marennes Oléron District - which comprises the district planning communities of Oléron Island (composed of eight districts) and the Marennes Basin (seven districts) - the main challenges are: the protection of coastal environments (sand dunes and wetlands) and associated valuable landscapes threatened by the expansion of construction, the maintenance of traditional economic activities, the reduction of traffic jams in summer, the increase of tourism revenues in order to maintain jobs, and the improvement of the quality of the tourist experience.

\subsection{A new policy for the implementation of ICZM: the OCQP}

\subsubsection{From the emergence of an ICZM project}

In 2005 , on the basis of a bottom-up procedure aiming at encouraging local initiatives in ICZM, the French Government financed twenty-five projects submitted by administrative divisions. As one of the successful candidates, the Marennes Oléron District developed an ICZM project focused on the sharing of concepts, databases, analysis (identification of major issues and challenges) and methods (establishment of key indicators for monitoring the sustainability of local development). In two years, this initiative had achieved two main results: 
the construction of a network that included the majority of coastal stakeholders and the building of a shared vision of the future.

In 2007, as this incentive programme came to an end, at stake was the consolidation of its gains through the implementation of a practical project that could demonstrate the ability of ICZM to support the resolution of coastal problems at the local scale.

\subsection{2 ... to the launch of the OCQP}

In 2007, the "Beach Plan", which was created in 2003 by the District Planning Community of Oléron Island to improve beach quality, came into its implementation phase. At the end of 2007, the adoption of the "Beach Charter", that regulates beach protection and development, was the first operational step of the OCQP, which aimed to improve beach quality through integrated beach management. This project appeared to offer a good opportunity to carry out the ICZM initiative in the field. Consequently, at the beginning of 2008, it was designated as the first practical attempt to apply ICZM principles.

Thus, the main objective of the OCQP is to improve beach quality through a wide range of measures: 1) security reinforcement on the beach and in the bathing area through the installation of new security posts; 2) strengthening of environmental protection through site redevelopment; 3) upgrading of the tourist experience through the improvement of signalization, facilities and services. The identification of beach types is a main goal of the OCQP, as it will allow users to choose beaches that suit their requirements.

\subsubsection{The "Qualibeach" research programme as a support for the OCQP}

Three main factors led to the creation and launch of the applied research programme known as "Qualibeach" in support of OCQP implementation: the high demand from decision-makers for knowledge strengthening and territorial analysis, the proposal to make Oléron Island a laboratory for innovative experiments in the field of sustainable development, and the helpful participation of scientists in the ICZM project between 2005 and 2007. As a consequence, the regional authorities decided to support the establishment of this programme for the period of 2008 to 2012 (Fig. 2).

This programme pursues three main objectives. The first is the production of additional data in certain fields: (a) beach attendance, through quantitative and qualitative approaches (identification of beach users and the temporal and spatial variations in beach attendance that occur during the peak season); (b) coastal activities (identification of types of beach usage and their spatial distribution); c) land and water-use conflicts, particularly at the interface between bathing and water sports; d) beach quality perception (global appreciation and determining factors of beach quality); e) user preferences with regard to facilities. One of the main outcomes of this work will be the construction of a new beach typology based on beach usage and the production of a beach guide for visitors.

The second objective of "Qualibeach" is to set up an assessment procedure aimed at evaluating beach quality through the development of key indicators. Three major areas were identified for assessment: 1) environmental quality, 


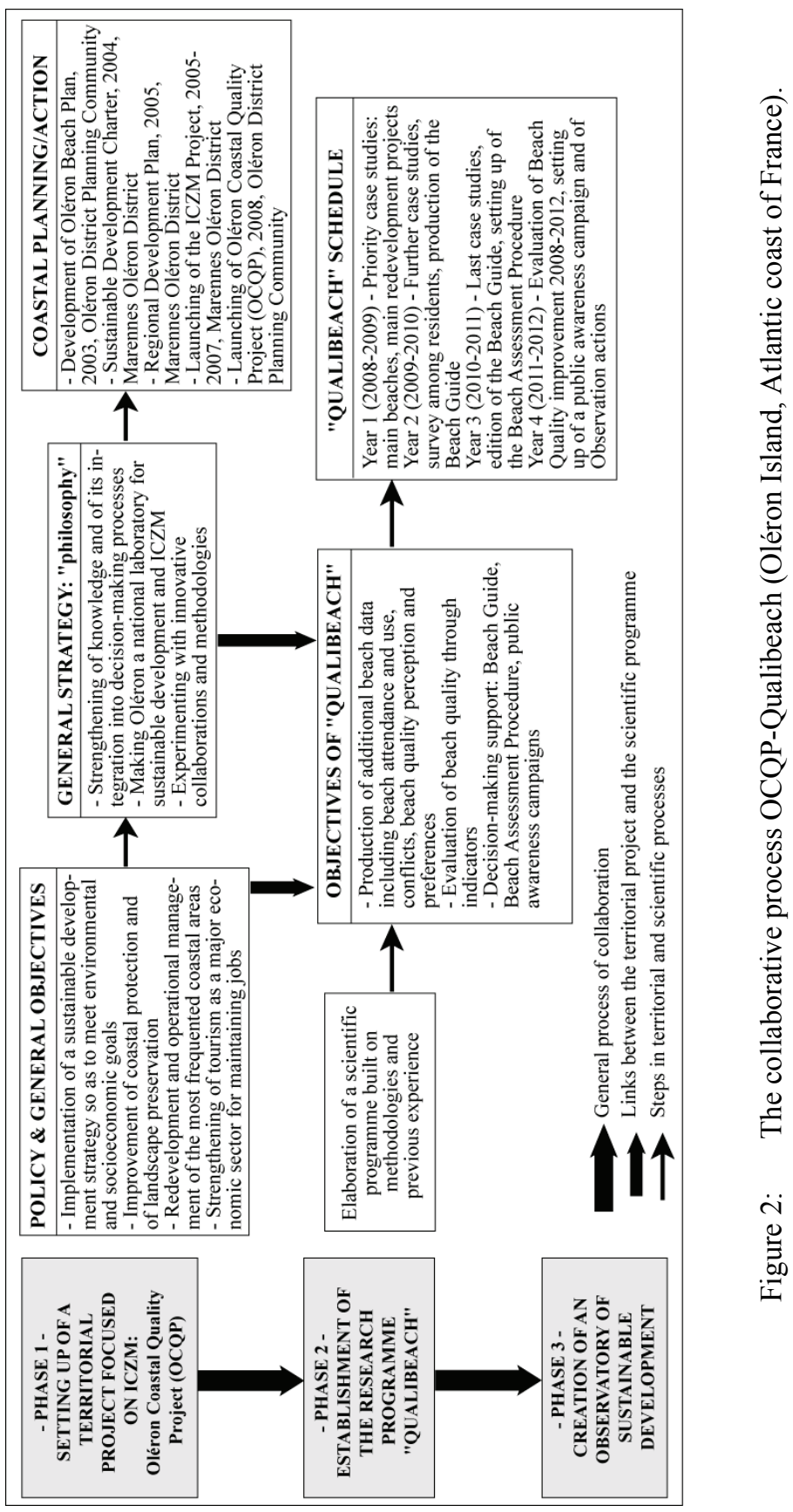

WIT Transactions on Ecology and the Environment, Vol 139, (C) 2010 WIT Press www.witpress.com, ISSN 1743-3541 (on-line) 
including the state of the beach/dune system, sanitary conditions (management of sewage and litter) as well as ecological factors, such as habitats and species; 2) facilities, in quantitative and qualitative terms, according to four main criteria which are diversity, security, comfort and information; 3) "mixed" factors that are affected by a combination of natural and anthropogenic influences, such as landscapes, site assets for sporting activities and beach atmosphere.

The third "Qualibeach" objective is to support decision-making through various strategies. The first is the establishment of the study's annual schedule with decision-makers so as to adapt to their needs. This modus operandi is especially relevant for the OCQP as it is based upon a bottom-up approach by which a district has to apply for beach improvements at the District Planning Community, which means that the beaches to be redeveloped and upgraded were not identified at the beginning of the OCQP. Thus, an annual plan of beach improvements and related scientific studies is made every year. The reactivity and flexibility of "Qualibeach" in spatial (choice of sites to study) and temporal (when to conduct a beach study) terms are two main conditions that this programme fulfils to provide effective support for decision-making. Therefore, studies are conducted both before and after field interventions, so as to allow the analysis of existing situations (what are the main problems to be addressed? What are the opinions and preferences of users?), and to evaluate new developments for operational performance and level of satisfaction (have the issues in question been solved and are beach users satisfied?). The second strategy adopted to meet the needs of practitioners consists in the formulation of decision-making tools. One of these tools is a Beach Guide that aims to provide all stakeholders with the same level of information on beach characteristics and beach quality in order to encourage action on beach improvements and to facilitate decision-making. The Beach Guide will be updated every year so that changes can be integrated. A second important tool designed for the District Planning Community that is in charge of the OCQP is a simplified beach assessment procedure based upon a simple checklist to be completed by trained personnel during field visits. The checklist will be in a grid format and will show the criteria of the global assessment procedure that are subject to rapid change. The third strategy in support of decision-making aims to integrate public participation into the resolution and prevention of beach issues. It is built on two major statements: 1) citizens can provide effective support for the improvement of the state of beaches regarding litter and the maintenance of public facilities; 2) information and awareness campaigns are necessary to gain the public interest and participation in the OCQP. In addition, setting up a communication campaign was identified as the best way to change public opinion on some matters, such as the accumulation of algae or pebbles on beaches at certain times. Indeed, most tourists consider that algae and pebbles spoil beaches and expect local authorities to systematically remove them. The diffusion of information on the positive roles of algae and pebbles might encourage their acceptance. 


\section{Results and discussion}

Some of the achievements of the "Qualibeach" research programme are described below illustrating how research can support decision-making and sustainable development at the local scale to the benefit of coastal residents and tourists, in order to achieve both environmental and socioeconomic goals.

\subsection{Carrying out a study to support the development of a beach plan at La Giraudière beach (Grand-Village district, SW)}

La Giraudière Beach is an attractive isolated beach belonging to the remarkable beach/dune system that formed on the windward coast of Oléron Island. It is affected by rapid erosion that threatens the existing car park. Here, the main challenge is to protect the dune from human-induced degradation, which is accelerating the rate at which the coastline is receding whilst also maintaining beach accessibility for all visitors. Indeed, this beach is one of the most frequented by residents and tourists. In this situation, the forthcoming beach plan, to be formulated and implemented between 2009 and 2011, will have to take into account both the vulnerability of the dune system as well as the threat posed by beach erosion to infrastructures and facilities. Thus, in accordance with practitioner needs, the main objectives of the La Giraudière case study, which was conducted in August 2009, were: (1) to produce quantitative and qualitative data on beach users in order to take visitor profiles and preferences into account into the future beach plan; (2) to hear the opinions of beach users regarding the first draft of the beach plan, and more particularly on the planned relocation of the car park to a site further away from the beach access and on the promotion of environmentally-friendly public transport; (3) to make a global review of coastal issues so as to include their resolution in the beach plan.

Various methods were employed to generate the data: (a) counting campaigns related to vehicle traffic and beach attendance during the peak season (from July $15^{\text {th }}$ to August $15^{\text {th }}$ ); (b) a survey of 418 beach users (residents and tourists); (c) interviews with lifeguards, sport centre employees and restaurant owners to get their point of view on coastal issues; (d) field data collection (in particular, recording car number plates to identify the geographical origin of visitors, and the compilation of a list of facilities with details of their current condition).

The main results are summarized in tables 1 and 2 . The study provided useful data to decision-makers on beach user practices and opinions, showing that: 1) a high proportion of beach users already use an environmentally-friendly means of transport to visit the beach, and most are favourable towards the development of such transport; 2) $78 \%$ of beach users approve of the car park relocation and are happy to use shuttles or bicycles to go from the car park to the beach; 3 ) the main issues can be resolved by site redevelopment, in particular by zoning beach activities, relocating car parks and through the reorganization of traffic; 4) permanent residents generally have the same opinion as other beach users on beach quality (see Table 2) and on planned reorganization and redevelopment 
Table 1: $\quad$ Main characteristics of la Giraudière beach, Oléron Island (France).

\begin{tabular}{|c|c|c|}
\hline CHARACTERISTICS & \multicolumn{2}{|l|}{ RESULTS } \\
\hline Beach attendance & \multicolumn{2}{|c|}{$\begin{array}{l}\text { Peak hours }(5 \text { p.m.): } 3724 \text { persons - Peak days: } 5422 \text { persons } \\
\text { Status: } 54 \% \text { tourists }(62 \% \text { staying in neighbouring villages), } 24 \% \text { day } \\
\text { trippers, } 15 \% \text { secondary residents, } 7 \% \text { permanent residents } \\
\text { Group description: family and/or friends: } 61 \% \text {; one adult with young } \\
\text { children: } 20 \% \text {; lone adult: } 17 \% \text {; others: } 2 \% \\
\text { Beach equipment ( } \% \text { of groups that brought...): chairs: } 6,2 \% \text {; beach } \\
\text { umbrellas: } 20,9 \% \text {; surfboard: } 2,5 \% \text {; body board: } 44,4 \% \\
\text { Distribution of beach users at peak hours: } 40 \% / 18 \% \text { on the dry } / \text { wet } \\
\text { beach; } 18 \% \text { on the dune; } 16 \% \text { in the bathing area; } 8 \% \text { on the surf spot } \\
\text { Main activities: rest and sun-tanning: } 36 \% \text {; bathing: } 31 \% \text {; walking and } \\
\text { conversation with family and/or friends: } 9 \% \text {; beach games: } 8 \% \text {; water } \\
\text { sports: } 7 \% \text {; shellfish collection/nature watching: } 5 \% \text {; picnic: } 4 \%\end{array}$} \\
\hline $\begin{array}{l}\text { Main reasons for } \\
\text { choosing this beach }\end{array}$ & \multirow{2}{*}{\multicolumn{2}{|c|}{$\begin{array}{l}\text { Environmental/natural assets: } 35 \% \text {; Proximity of place of residence: } \\
26 \% \text {; Sports activities: } 14 \% \text {; Good beach accessibility: } 11 \% \\
\text { Motorized vehicles (mainly cars): } 62 \% \text { ( } 3324 \text { persons); bicycles: } 18 \% \\
\text { ( } 980 \text { persons); by foot: } 13 \% \text { ( } 723 \text { persons); by tourist train: } 6 \%(350 \\
\text { persons); motorbike: } 1 \% \text { ( } 45 \text { persons) }\end{array}$}} \\
\hline $\begin{array}{l}\text { Means of transport } \\
\text { used to come to the } \\
\text { beach }\end{array}$ & & \\
\hline $\begin{array}{l}\text { Appreciation of beach } \\
\text { quality }\end{array}$ & $\begin{array}{l}\text { Opinion of tourists, secondary } \\
\text { residents and day trippers } \\
\text { Excellent: } 13 \% ; \text { good: } \quad 65 \% ; \\
\text { medium: } 21 \% \text {; low: } 1 \%\end{array}$ & 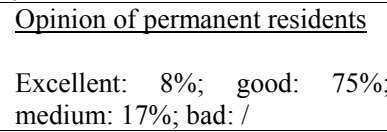 \\
\hline
\end{tabular}

Table 2: $\quad$ Current issues at La Giraudière beach, Oléron Island (France).

\begin{tabular}{|l|l|}
\hline ISSUE & CAUSES \\
\hline $\begin{array}{l}\text { Litter: overflow of dustbin at the entry of } \\
\text { the beach; litter accumulation in the dune }\end{array}$ & $\begin{array}{l}\text { Other dustbins not used; litter brought by the } \\
\text { sea/by users; campfires in dunes }\end{array}$ \\
\hline $\begin{array}{l}\text { Dune degradation: dune erosion and } \\
\text { fragmentation }\end{array}$ & $\begin{array}{l}\text { Intense marine and wind erosion; use of quads in } \\
\text { dunes; tracks in dunes; installation of beach users } \\
\text { in dunes (due to absence of beach at high tide) }\end{array}$ \\
\hline $\begin{array}{l}\text { Parking: dangerous parking along road and } \\
\text { by beach access; illegal parking in rescuers } \\
\text { parking space ; 45\% of bicycles not left in } \\
\text { cycle racks }\end{array}$ & $\begin{array}{l}\text { Lack of parking space/excessive use of cars to } \\
\text { travel to beach; low respect for regulations and } \\
\text { low level of enforcement; inappropriate location of } \\
\text { bicycle parking }\end{array}$ \\
\hline $\begin{array}{l}\text { Security: dangerous beach access path (risk } \\
\text { of falling); lack of security on the beach and } \\
\text { in the bathing area }\end{array}$ & $\begin{array}{l}\text { Unsuitable duckboards; inappropriate location of } \\
\text { the security post; beach users taking rescuers } \\
\text { parking space; lack of visitor information }\end{array}$ \\
\hline $\begin{array}{l}\text { Water-use conflicts: } 10 \% \text { of beach users } \\
\text { say that they had already experienced } \\
\text { conflicts with other users }\end{array}$ & $\begin{array}{l}\text { Lack of information on beach activity zoning; } \\
\text { absence of a buffer zone between bathing and } \\
\text { surfing areas }\end{array}$ \\
\hline
\end{tabular}

which means, firstly, that the benefits of the OCQP can suit the needs of all beach users and secondly, that tourism policies aimed at improving the quality of tourist beaches can also be valuable from the point of view of the wider society.

This case study also demonstrates that environmental and socioeconomic goals and challenges can be compatible, and that some actions, such as the relocation of car parks and traffic reorganization, can bring both environmental (better protection of dunes) and socioeconomic benefits (improvement of landscape quality and site functionality). 


\subsection{Carrying out a public survey to assess the success of a redevelopment plan at la Brée-les-Bains beach (NE)}

La Brée-les-Bains beach is a village-associated beach located on the northeastern coast of Oléron Island. It was the first beach to be redeveloped and equipped with diverse facilities (new security post, toilets, dustbins, phone box...) within the framework of the OCQP. In this instance, the study conducted in July 2009 pursued two main objectives: (1) canvassing beach user opinion on the upgrading of beach facilities and the general redevelopment of the site; (2) determining whether beach users were favourable or not to the strengthening of the urban profile of this beach (development of organized activities in the evening, creation of a commercial and lively sea front for pedestrians...). By questioning public preferences regarding both the functions and identity of the beach (urban beach or seaside tourist beach?) and on the best way to integrate the beach into village life, it was possible to assess beach user interest in sites that offer more of an urban atmosphere and, therefore, to evaluate the consistency of a policy of resort diversification. Thus, this aspect of the study was intended to support the work into the redefining of beach types in the light of beach user practices and preferences. In parallel, a supplementary public survey was conducted on Oléron's most "urban" beach (La Boierie) regarding its facilities and integration into municipal and port dynamics, this allowed the evaluation of the public interest for the expansion of such a beach model on Oléron Island.

Our study found that $89 \%$ of beach users are satisfied with the new beach facilities. In addition, the survey found that $97 \%$ of beach users are either tourists $(61 \%)$ or secondary residents $(36 \%), 75 \%$ of which are regular visitors with a level of attachment to the site to the extent that they would probably choose another destination if the identity of the beach was not preserved. Moreover, such visitors are very demanding, which can be illustrated by their complaints about the closure of the children's club and also the unusual accumulation of algae on the beach. As a result, $70 \%$ of this group considered the beach to be of bad quality in 2009 .

These results show that redevelopment projects aimed at upgrading the level of services on a beach or a seafront can be poorly understood or not accepted by the public. On the other hand, surveys conducted on less equipped "natural" beaches revealed that the public was favourable to facilities and services. In conclusion, we content that in tourist areas frequented by regulars, visitors can be attached to a site's identity and more globally to that of the region, and therefore may be unfavourable towards change.

\subsection{Assessing the importance of beach development models: the example of Gatseau beach (Saint-Trojan, SE)}

With the same perspective, a survey was conducted on the beach of Gatseau, located at the south-eastern end of Oléron Island, considered by the National Forestry Office as the island's best developed "natural" beach. The purpose was to canvass beach user opinion so as to determine whether it would be appropriate or not to apply this beach model to the south-western coast. The survey's results 
showed that the public was satisfied with the development model of this site, but that this beach had particular characteristics that would prohibit the transfer of its organizational structure to wilder and more sport-focused sites.

\section{Conclusion: benefits and difficulties of the OCQP}

One of the main benefits of the OCQP was the establishment of a fruitful relationship between decision-makers and scientists that led to mutual reward. From a scientific point of view, the experience developed in this project has already had several benefits, the first being the reinvigoration of scientific opinions on key concepts such as "quality". The subjective aspect of "quality", has already been emphasized by Pereira et al. [6] and Cervantes and Espejel [10]; and this study has confirmed the importance of the issue for achieving sustainable objectives since the divergence of views on quality, which has its roots in differences in culture and goals, appeared as a factor of conflict or misunderstanding among decision-makers themselves, and also between decision-makers and beach users. In terms of coastal management, this appraisal means, firstly, that beach quality must be considered as a societal project - the cooperative nature of this project being the only way to promote a common vision of the coast for the future and therefore for the implementation of coastal policies - and, secondly, that the "objective quality" measured through criteria based upon regulations and scientific expertise must be given to the public so that the diverse viewpoints can gradually be drawn together. A second scientific benefit of OCQP experience is that the views and concerns of practitioners are valuable for scientific problems as they bring different questions to those identified by the scientific community and they also put forward new questions over time. Thirdly, this experience gives researchers the practical opportunity to experiment with new methodological tools, such as quality indicators, with the advantage of getting immediate results on their applicability.

One of the main difficulties that the District Planning Community of Oléron Island had to address was of a financial nature. The enforcement of European regulations meant that it would be very expensive to clean up Second World War debris and also a rubbish dump that has been stripped by dune erosion at SaintTrojan beach (SW). As a consequence, the redevelopment plan for this beach has been suspended for two years with no resolution to the situation evident. Another issue is the delay in the implementation of some redevelopment plans due to severe differences between the parties involved.

\section{Acknowledgements}

The author is grateful to the Poitou-Charentes Regional Authorities and to the District Planning Community of Oléron Island for supporting the research programme "Qualibeach". She also thanks for fruitful collaboration the National Forestry Office. 


\section{References}

[1] Morgan, A.R. and Williams, A.T., Sociodemographic parameters and user priorities at Gower beaches, UK. In: Healy, M.G. and Doody, J.P. (eds), Directions in European Coastal Management. Cardigan, Wales, UK: EUCC \& Samara Publishing Ltd, pp. 83-90, 1995.

[2] De Ruyck, A.M.C., Soares, A.G., McLachlan, A., Factors influencing beach choice on three South African beaches: a multivariate analysis. Geojournal, 36(4), pp. 345-352, 1995.

[3] Morgan, R., A novel, user-based rating system for tourist beaches. Tourism Management, 20, pp. 393-410, 1999.

[4] Cendrero, A. \& Fischer D.W., A procedure for assessing the Environmental Quality of Coastal Areas for Planning and Management. Journal of Coastal Research, 13(3), pp. 732-744, 1997.

[5] Cendrero, A., Frances, E., Del Corral, D., Fernan, J.L., Fischer, D., Del Rio, L., Camino, M., Lopez, A., Indicators \& indices of environmental quality for Sustainability Assessment in Coastal Areas. Application to case studies in Europe and the Americas. Journal of Coastal Research, 19(4), pp. 919933, 2003.

[6] Pereira, L.C.C., Jimenez, J.A., Madeiros, C., Marinhada Costa, R., The influence of the environmental status of Casa Caiada and Rio Doce beaches (NE Brazil) on beach uses. Ocean and Coastal Management, 46, pp. 10111030, 2003.

[7] Micallef, A., Williams, A.T., A novel bathing area registration evaluation system: the Dalmatian (Croatia) coast. Journal of World Leisure, 46(4), pp. 4-21, 2004.

[8] Ergin, A., Williams, A.T., Micallef, A., Coastal scenery: appreciation and evaluation. Journal of Coastal Research, 22(4), pp. 958-964, 2006.

[9] Ergin., A., Micallef, A., Williams, A.T., Coastal scenic evaluation of Gozo/Gomino, Malta, as a tourist product. International Congress of Lille, France, Les littoraux: subir, dire, agir, $16^{\text {th }}$ to $18^{\text {th }}$ Jan. 2008, http://www.meshs.fr/documents/pdf/publications/actes/colloque_litto $\mathrm{ral} /$ Ergin

[10] Cervantes, O. \& Espejel, H., Design of an integrated evaluation index for recreational beaches. Ocean and Coastal Management, 51, pp. 410-419, 2008.

[11] Duvat, V., Étude de la fréquentation estivale et de la perception de la qualité des plages par les estivants sur l'île d'Oléron. Programme de recherche "Qualiplages", convention n8/RPC-R-004 du 21/01/08. Rapport de résultats $\mathrm{n}^{\circ} 1,81$ p., 2009.

[12] Vacher, L. (dir.), Paradis, L., Atlas de la fréquentation des plages de Charente-Maritime. Observatoire des Pratiques de Tourisme et de Loisir, LIENSs publications, La Rochelle, 260 p., 2010. 